REPORTS OF MORPHOLOGY
Official Journal of the Scientific Society of Anatomists,
Histologists, Embryologists and Topographic Anatomists
of Ukraine
journal homepage: https://morphology-journal.com

\title{
Features of vaginal microbiocenosis in women of reproductive age with overweight and obesity
}

Gasparyan K.A. ${ }^{2}$, Kondratyuk V.K. ${ }^{1,2}$, Ponomareva I.G. ${ }^{2}$, Kondratyuk K.O. ${ }^{3}$, Dzis N.P. ${ }^{4}$, Lisyana T.O. ${ }^{2}$

${ }^{1}$ P.L.Shupyk National University of Health of Ukraine, Kyiv, Ukraine

${ }^{2}$ Institute of Pediatrics, Obstetrics and Gynecology named after Academician O.M.Lukyanova National Academy of Medical Sciences of Ukraine, Kyiv, Ukraine

${ }^{3}$ Bogomolets National Medical University, Kyiv, Ukraine

${ }^{4}$ National Pirogov Memorial Medical University, Vinnytsya, Ukraine

\section{ARTICLE INFO}

Received: 14 December, 2020

Accepted: 18 January 2021

UDC: 616.98:616.12-008.318-053.8

CORRESPONDING AUTHOR

e-mail: nata.d55@ukr.net

Dzis N.P.
Overweight and obesity play a negative role in gynecological and obstetric practicE.In women, the frequency of infectious pathology increases against the background of metabolic disorderS. The most common form of infectious vaginitis is bacterial urogenital candidiasis, in the etiological structure of which a significant role belongs to the fungi Candida albicans, as well as Candida non-albicans: C.glabrata, C.tropicalis, C.parapsilosis, C.krusei. Associations of Candida fungi with various representatives of opportunistic microflora, such as gram-positive and gram-negative aerobic, facultativeanaerobic and obligate-anaerobic microorganisms, are often formed. As a result, numerous bacterial pathogens multiply and the number of lactobacilli, which are usually part of the bacterial flora of the vagina, is significantly reduced. In bacterial vaginosis (BV), the concentration of anaerobic pathogens Peptostreptococcus sp, Gardnerella vaginalis, Peptostreptococcus Mobiluncus sp, Mycoplasma hominis can increase 100 timeS.Activation of Atopobium vaginae and Gardnerella vaginalis, which play a "key" role in the pathogenesis of BV, has been proven. The aim of the study was to study changes in the vaginal microbiome in women with candidiasis and bacterial vaginosis in order to improve existing treatment regimens. We examined 120 women of reproductive age with overweight and obesity. The degree of microbial contamination was determined and the maximum possible spectrum of aerobic and facultative-anaerobic microflora was detected. In women with vulvovaginal candidiasis, overweight and obesity, a high concentration (Ig5.8 CFU/ml) of Candida fungi was found, and in $95 \%$ of patients two-, three- and four-component associations of Candida fungi with various representatives of conditional pathogenic microflora. Lactobacillus deficiency was found in $58.3 \%$ of patients, and their complete absence - in 10.0\%. Bacteriological examination of the vaginal contents of women with vaginosis and obesity revealed significant dysbiotic disorders of the vaginal microflora, three-, four- and even five-component associations of anaerobic and facultative anaerobic microflora with a predominance of anaerobeS.A low seeding level of lactobacilli (Ig2.2 CFU/ml) was established. Thus, the gram-positive anaerobic and facultative anaerobic microflora of Firmicutes have a significant share in the spectrum of vaginal microflora in overweight and obese patients, in contrast to non-obese women of reproductive agE.In women of reproductive age with vulvovaginal candidiasis and obesity, in contrast to non-obese patients, a higher frequency of fungal-bacterial associations, a higher quantitative level of vaginal contamination by Candida albicans and non-albicans with a lack or general absence of lactoflora.

Keywords: overweight, obesity, microbiocenosis, bacterial vaginosis, urogenital candidiasis.

\section{Introduction}

Obesity is a significant medical and social problem of our time, the relevance of which is primarily related to the growing prevalence and the threat of the formation of various pathological human conditions [1, 2, 18, 23, 27]. Obesity and overweight play an important negative role in gynecological and obstetric practicE.There is information 
that in women against the background of metabolic disorders increases the frequency of infectious pathology of various habitats, including the urogenital tract $[6,12,19$, $20,28]$.

According to the prevalence of urogenital infections in women, one of the leading places is urogenital candidiasis $[3,21,22,26]$. The most common causative agent of candidiasis is the fungus Candida albicans.But in the last decade in the etiological structure of candidiasis there is a tendency to increase the proportion of fungi Candida nonalbicans: C.glabrata, C.tropicalis, C.parapsilosis, C.krusei [10]. A sign of modern genital candidiasis is the formation of associations of fungi of the Candida with various representatives of opportunistic pathogenS.Associations with Candida fungi may include gram-positive and gramnegative aerobic, facultative-anaerobic and obligateanaerobic microorganisms [29].

Firmicutes have a significant proportion in the bacterial spectrum of the vagina. Catalase-positive and coagulasenegative staphylococci in the vaginal microbiocenosis occur in more than $50 \%$ of women, Streptococcus spp. and Enterococcus spp. - in $30-40 \%$ of caseS.Anaerobic grampositive cocci (Peptococcus spp., Peptostreptococcus spp.) are detected with a frequency of $30-80 \%$. Gram-negative anaerobic rod-shaped bacteria contaminate the female genital tract with considerable frequency: Prevotella spp., Bacteroides spp., Porphyromonas spp., Fusobacterium spp., Veilonella spp [17]. Among enterobacteria, as factors of infectious pathology of genitals, a significant role belongs to Escherichia coli, Klebsiella spp., Enterobacter spp. and others [13]. Lactobacilli occupy a dominant position in the microflora of the vagina and cervix. Bifidumbacterium are excreted from the genital tract with less frequency. Lactobacilli are a marker of the normal microbiocenosis of the genital tract. It is lactobacilli that determine the degree of colonization resistance of the vagina $[8,9,15,16]$.

One of the most common dysbiotic disorders of the vaginal microbiota is bacterial vaginosis $(\mathrm{BV})$, which should be considered as an infectious non-inflammatory syndrome associated with dysbiosis of the vaginal habitat $[5,24,25,30]$.

The main manifestations of this pathology are a decrease or absence in the microflora of the vagina lactobacilli and activation of Atopobium vaginae and Gardnerella vaginalis, which play a "key" role in the pathogenesis of bacterial vaginosiS.Atopobium vagina is able to block factors of nonspecific reactivity (complement system), leads to increased inflammation in bacterial vaginosis, is a competitor of lactobacilli in terms of glycogen consumption. Data from the scientific literature indicate that metabolic disorders in women contribute to the active growth of Gardnerella vaginalis, which produce a specific toxin (cytolysin) that can cause desquamation of vaginal endothelial cells $[4,7,14]$.

An important component of the bacterial spectrum in bacterial vaginosis is Mobiluncus spp. This microorganism produces a toxin that inhibits the adhesion of lactobacilli on vaginal epithelial cells [11].

Given the high prevalence at the present stage of candidiasis and bacterial vaginosis of the genital tract, the negative impact of these diseases on the female reproductive system, the aim of our work was to study changes in vaginal microbiome in patients of these categories to improve existing treatment regimens.

\section{Materials and methods}

In order to solve the tasks of our work, we surveyed 120 women of reproductive age with overweight and obesity. For comparison, 60 women without overweight and obesity were examined. All women were divided into groups: Group I - women with vulvovaginal candidiasis and overweight and obesity (60 women); Group II - women with vulvovaginal candidiasis without excess weight and obesity (30 women); Group III - women with bacterial vaginosis and overweight and obesity (60 women); Group IV - women with bacterial vaginosis without excess weight and obesity (30 women). Data obtained from a survey of 30 healthy women were used as controls.

Carrying out of microbiological researches and the account of results was carried out according to the Order №234 of the Ministry of Health of Ukraine from 10.05.2007 and other regulatory documents.

The following differential diagnostic media were used to inoculate the genital mucus: blood agar, yellow-salt agar, Endo, Sabouraud agar, MRS medium for lactobacilli, Blaurok medium for bifidobacteria. Crops were carried out by the method of sector seeding on dense nutrient media, which allows to determine the degree of microbial contamination and to identify the maximum possible spectrum of aerobic and facultative anaerobic microflora.

Gardnerellosis was diagnosed by bacterioscopy by staining with Romanovsky smears with subsequent counting of "key" cells, amine test, determination of $\mathrm{pH}$.

The contents of the vagina of women for the presence of fungi Candida were examined by microscopy and culture bacteriological method. Sabouraud agar was used to identify yeast-like fungi. MICROLA-TEST kits "Candidatest 21" (Erba Lachema s.r.o. (Czech Republic)) were used for further identification of isolated yeast-like fungi.

Determination of anaerobic microorganisms was carried out according to the guidelines "Laboratory diagnosis of purulent-inflammatory diseases caused by asporogenic anaerobic microorganisms", Kharkiv, 1985.

The anaerobic microflora of the genital tract was studied with strict adherence to the technique of anaerobic cultivation. Thioglycollate medium, blood agar with glucose, liver broth, Kitt-Tarozzi medium were used for the study. The "Anaerocult" system (Merck, Germany) and the "Anaerogas" gas packages were used to create anaerobic conditionS.MICROLA-TEST "Anaerotest 23" kits (Erba Lachema s.r.o. (Czech Republic)) were used for further identification of isolated anaerobic microorganisms. 
Identification of microorganisms was performed by their cultural and morphological characteristicS.When identifying the isolated microorganisms, the Bergey's classification was followed.

To assess the contamination of the genital tract was carried out quantitative accounting of colonies that grew in dense nutrient media. The content of opportunistic pathogens in the test material was expressed by the number of colony-forming units in $1 \mathrm{ml}(\mathrm{CFU} / \mathrm{ml})$ of biological material.

Statistical analysis of the obtained research results was performed using standard computer packages "Data Analysis" Microsoft Excel for Windows 2002.

\section{Results}

The results of microscopy of the contents of the vagina in most women of group I with vulvovaginal candidiasis indicate negative changes in the microbiota, which have manifestations of vaginitiS. In $83.3 \%$ of patients there was a significant increase in the number of neutrophils and leukocytes (30-100 in the field of view), increased epithelial desquamation, degenerative changes of the nuclei, vacuolation of the cytoplasm, deficiency or absence of normal morphotype microflora, a significant increase in gram-positive and gram-negative organisms. In $46.7 \%$ of the examined fungi were in the form of yeast cells, in $53.3 \%$ yeast and pseudomycelium were found.

In $6.7 \%$ of obese women, against the background of a moderate number of yeast cells, no manifestations of vaginitis were detected, but there was an accumulation of gram-positive cocci and gram-negative rods, as well as an increase in root-like bacteria and fusobacteria.

Examination of the contents of the vagina by bacteriological culture revealed that in patients of group I, Candida fungi were sown in all subjects at a significant concentration (lg5.8 CFU/ml).

In $95 \%$ of patients the formation of associations of fungi of the Candida with various representatives of opportunistic pathogenic microflora was revealed. Two-component bacterial-fungal associations were found in $28.3 \%$ of cases, three-component - in $48.3 \%$, four-component - in $18.3 \%$ of patientS.Monocultures of Candida fungi were registered in $5.1 \%$ of women.

Associative forms of vaginal dysbiosis differ from monomicrobial ones by greater aggressiveness, significant resistance to antibacterial drugs, severe structural changes in the vaginal mucosa.

As a result of bacteriological examination of women of group I, an increase in the composition of bacterial-fungal associations of the vaginal contents of Firmicutes, in particular, cocci with pathogenic properties was found. Thus, the frequency of the presence of S.aureus in the associations in women of group I reached $18.3 \%$, epidermal staphylococcus with hemolysis - $23.3 \%$, enterococcus $20.0 \%$.

Also, the associations of women of group I with a

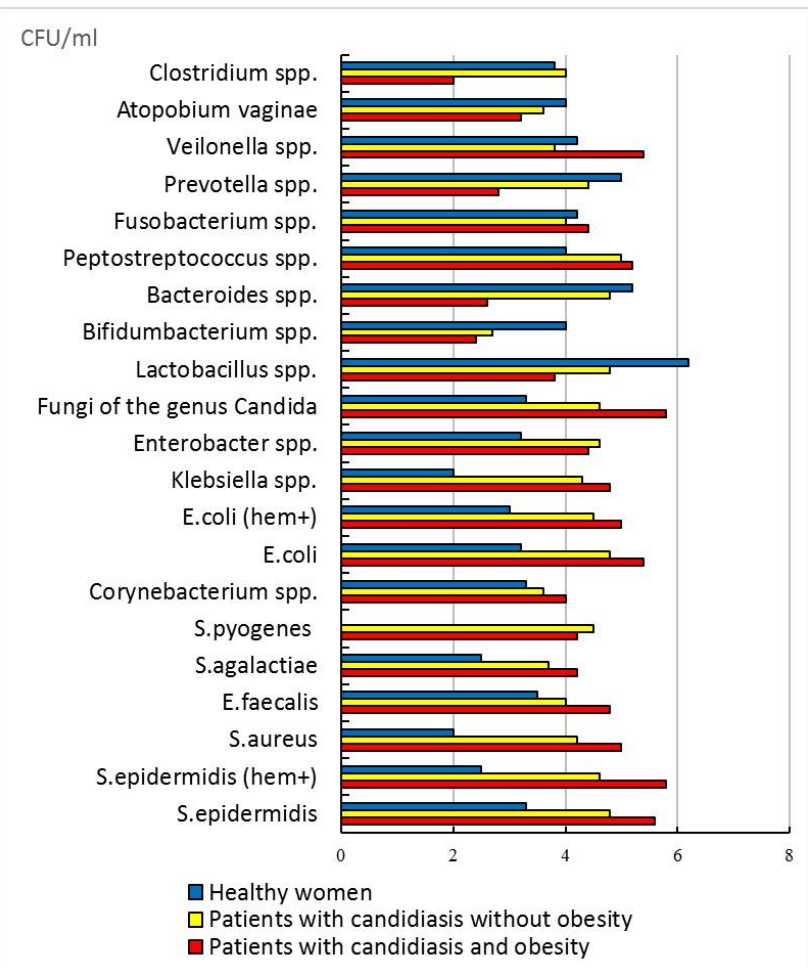

Fig. 1. Comparative diagrams of the composition of vagina microflora healthy women and women of reproductive age with vulvovaginal candidiasis and obesity.

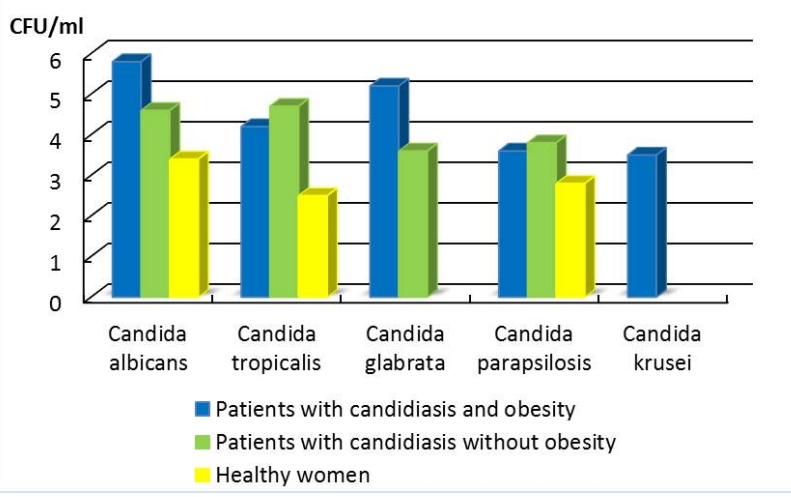

Fig. 2. Comparative diagrams of the species spectrum of Candida fungi of healthy women and women of reproductive age with vulvovaginal candidiasis and obesity.

significant frequency included different types of enterobacteria. A significant proportion was found in the associations of Escherichia coli with hemolytic properties (16.7\%), Klebsiella spp. - 15\%, Enterobacter spp. - 13.3\%. Quantitative seeding rates of various representatives of opportunistic vaginal microflora in patients exceeded the diagnostic level (lg4.2 - lg5.8 CFU/ml) (Fig. 1).

Lactobacillus deficiency was found in $58.3 \%$ of patients, and their absence - in $10.0 \%$. In $31.7 \%$ of cases, the registration rates of lactoflora were normal. Also in women of group I there was a decrease in the quantitative level of 


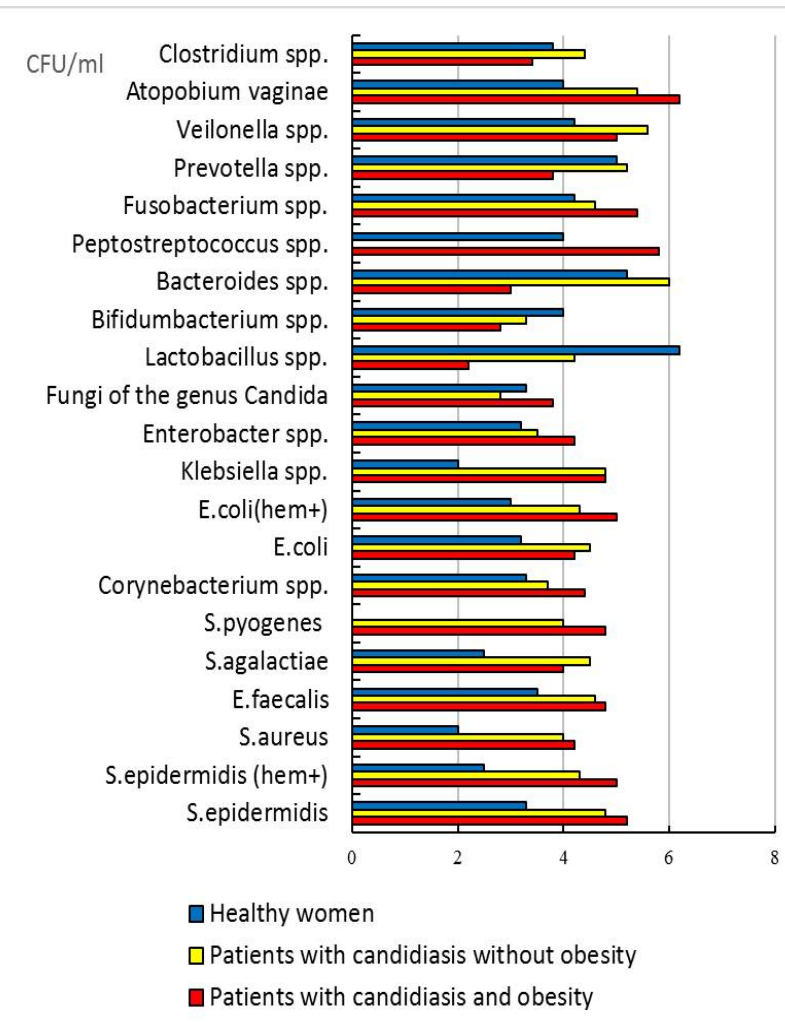

Fig. 3. Quantitative indicators of vaginal microflora of healthy women and women of reproductive age with bacterial vaginosis and obesity.

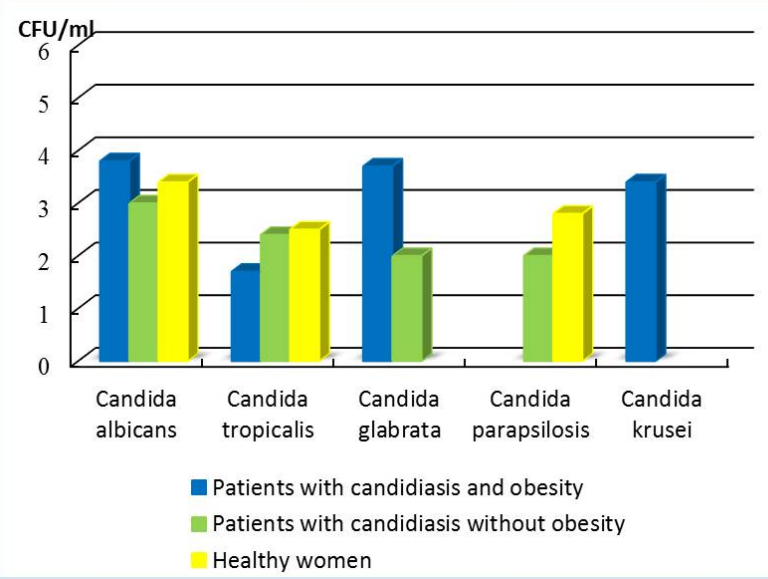

Fig. 4. Comparative diagrams of the species spectrum of Candida fungi of healthy women and women of reproductive age with bacterial vaginosis and obesity.

seeding lactobacilli.

According to the results obtained with the highest frequency, the vagina of patients of group I was contaminated with Peptostreptococcus spp. (28.3\%), Fusobacterium spp. $(16.7 \%)$ and Veilonella spp. (16.7\%). The presence of Bacteroides spp. (13.3\%), Prevotella spp. (10.0\%), Clostridium spp. $(6.7 \%)$ were registered with less frequency. The frequency of registration of Gardnerella vaginalis was only $3.3 \%$, Mobiluncus spp. $-1.7 \%$.
Quantitative seeding rates of individual members of the obligate anaerobic microflora exceeded the diagnostic level: Peptostreptococcus spp. - Ig5.2 CFU/ml, Veilonella spp. Ig5.4 CFU/ml, Fusobacterium spp. - Ig4.4 CFU/ml.

Quantitative level of vaginal contamination by Bacteroides spp., Clostridium spp., Prevotella spp. was reduced compared to normal (lg2.0 - Ig2.8 CFU/ml).

In order to compare the indicators of vaginal microecology, the second group of patients with vulvovaginal candidiasis without obesity was examined.

Examination of the contents of the vagina in patients of group II by microscopy shows a less significant than in patients of group I, an increase in the number of leukocytes (15-50 in the field of view), moderate destructive changes in epithelial cells, lower frequency of pseudomycelial form of fungi (yeast cells - $76.7 \%$, yeast cells and pseudomycelium - $33.3 \%$ ). Microorganisms belonging to lactobacilli by morphotype were found more frequently in obese women than in group I patients.

According to the results of the study of vaginal contents by bacteriological method in women of the second group, despite the significant frequency of formation of fungalbacterial associations $(83.3 \%)$, the quantitative indicators of individual microbiocenosis in the subjects did not reach the level found in patients of group I. Two-component associations were found in $46.7 \%$ of the surveyed, threecomponent associations in $36.7 \%$ and monocultures in $16.6 \%$.

The concentration of Candida fungi exceeded the norm and was Ig4.6 CFU/ml. Gram-positive coccal microflora with pathogenic properties and enterobacteria were associated with fungi with a lower frequency than in patients of group I, and in low concentrationS. In women of group II, the frequency of vaginal contamination of S.aureus was $13.3 \%$, S.epidermidis (hem+) $-16.7 \%$, Enterococcus faecalis $16.7 \%$, S.pyogenes $-6.7 \%$. The frequency of vaginal inoculation with enterobacteria in women was in the range of $10-16.7 \%$. Quantitative indicators of Firmicutes with pathogenic properties exceeded the diagnostic level $>\lg 4.0$ $\mathrm{CFU} / \mathrm{ml}$ ).

Some representatives of the anaerobic microflora in the vaginal associations in women of group II without obesity were registered with a higher frequency than in women of group I: Bacteroides spp. - 36.7\%, Clostridium spp. - 10\%, Prevotella spp. - $33.3 \%$. The frequency of registration of Gardnerella vaginalis was $6.7 \%$, Mobiluncus spp. - 3.3\%, Atopobium spp. - 3.3\%. Quantitative indicators of anaerobic seeding were in the range of $\lg 3.6-\lg 5.0 \mathrm{CFU} / \mathrm{ml}$.

The rates of vaginal contamination with lactobacilli in women of group II were higher compared to women of group I. Lactobacillus deficiency was found in $46.7 \%$ of patients. Lactoflora was not determined in $6.7 \%$ of patients.

Examination of women in group I with vulvovaginal candidiasis and obesity revealed contamination of the vagina with various species of Candida nonalbicanS.Candida glabrata $(10 \%)$ and Candida tropicalis 
$(6.7 \%)$ were detected with the highest frequency, and their quantitative indicators exceeded the diagnostic level. Candida parapsilosis and Candida krusei were sown with insignificant frequency (5\% and $3.3 \%$, respectively) (Fig. 2).

The species composition of Candida non-albicans in patients of the second group did not differ much from the species identified in women of group I. However, in the examination of women with vulvovaginal candidiasis without obesity, a lower frequency of vaginal inoculation with Candida non-albicans was found than in patients of group I. Candida tropicalis fungi were detected with the highest frequency $(10 \%)$ and at a lgconcentration of $4.7 \mathrm{CFU} / \mathrm{ml}$ in patients of group II. Other species of non-albicans in women of group II were registered with less frequency and in low concentration. Candida krusei was not detected in the spectrum of nonalbicans fungi isolated from the vagina in patients of group II.

The task also included the study of the peculiarities of changes in the microbiocenosis of the vagina in patients with bacterial vaginosis and obesity (group III). As a comparison, patients with vaginosis without obesity (group IV) were examined.

The results of microscopy of the contents of the vagina in women of group III with vaginosis indicate a significant presence of parabasal epithelial cells and "key" cells, the phenomenon of desquamation of the squamous epithelium, a significant density of coccal microflora and rodS.Leukocytes in the vaginal material were registered in moderation (1535 in the field of view). Morphotypes of microflora corresponding to lactobacilli were detected with insignificant frequency or were absent. The frequency of registration of fungi by microscopy did not reach a high level (yeast cells $15 \%$, yeast + pseudomycelium $-8.3 \%$ ).

Bacteriological examination of the contents of the vagina in patients of group III with vaginosis and obesity allowed to establish significant dysbiotic disorders of the vaginal microflora.

The results of the study of vaginal contents in patients of group III show that overweight and obesity are associated with a significant decrease in the frequency and quantitative indicators in the spectrum of vaginal microbiota of Bacteroidetes phylum, which includes Bacteroides and Prevotellaceae family and increased vaginal microflora representatives of Firmicutes.

Associations of anaerobic and facultative-anaerobic microflora with dominance of anaerobes were revealed in all examined patients of the III group. Three-component associations of bacterial flora were observed in $38.3 \%$ of patients, four-component associations in $45 \%$, and fivecomponent associations in $16.7 \%$.

Examination of the contents of the vagina showed that with the highest frequency in patients of group III were found Gardnerella vaginalis (83.3\%), Atopobium vaginae $(68.3 \%)$, Mobiluncus spp. (41.7\%). The presence of Atopobium vagina in the spectrum of vaginal microflora is a sign of recurrent diseasE.Also in the composition of bacterial associations in patients of group III, an increase in the frequency of registration of Peptostreptococcus spp. (43.3\%), Fusobacterium spp. (36.7\%), Veilonella spp. (31.7\%). Bacteroides spp., Prevotella spp. and Clostridium spp. were determined in associations with insignificant frequency (15.0\%, $11.7 \%$ and $8.3 \%$, respectively).

Quantitative indicators of vaginal contamination by obligate anaerobes in patients of group III significantly exceeded the norm. The diagnostic level of Peptostreptococcus spp., Fusobacterium spp., Veilonella spp., Atopobium vaginae exceeded the diagnostic level. Whereas quantitative seeding rates of Bacteroides spp. were at a low level - Ig3.0 CFU/ml (Fig. 3).

Among gram-negative facultative anaerobic rods in the associations of women with vaginosis with the highest frequency were E.coli $(18.3 \%)$, E.coli hem+ (13.3\%), Klebsiella spp. (16.7\%). Quantitative indicators of Firmicutes group III patients and intestinal microflora isolated from the vagina exceeded the diagnostic level (lg4.0 - $\lg 5.0 \mathrm{CFU} / \mathrm{ml})$.

In $16.7 \%$ of the surveyed women of group III, the presence of Candida fungi was detected in insignificant concentration (lg3.8 CFU $/ \mathrm{ml}$ ). The spectrum of Candida fungi included C.albicans - 8.3\%, C.glabrata - 5.0\%, C.tropicalis - $1.7 \%$, C.crusei $-1.7 \%$ (Fig. 4).

Dysbiotic changes of the vaginal microbiota in patients of group III were characterized by a significant decrease in vaginal contamination by representatives of the normal microflora - lactobacilli. The seeding rate of lactobacilli was $56.7 \%$, absence - $43.3 \%$. Quantitative seeding rates of lactobacilli were low (lg2.2 CFU/ml).

For comparison, we examined patients with vaginosis without obesity (group IV). According to microscopy, no significant leukocyte reaction was detected in the vaginal material (5-25 in sight). There was a significant increase in the number of "key" cells and an increase in the density of vaginal contamination with gram-positive and gram-negative microflora.

Bacteriological examination of the vaginal microbiome in patients with obesity without vaginosis revealed a lower frequency and lower quantitative level of vaginal contamination with obligate anaerobes and facultative anaerobic microflora. The anaerobic spectrum of the vaginal microflora included Gardnerella vaginalis $(73.3 \%)$, Atopobium vaginae (43.3\%), Mobiluncus spp. (30.0\%), Peptostreptococcus spp. (33.3\%) and Fusobacterium spp. $(20.0 \%)$. The frequency of registration of anaerobes exceeded that found in patients of group III: Bacteroides spp. - $56.7 \%$, Veilonella spp. - $46.7 \%$, Clostridium spp. - $46.7 \%$.

Quantitative indicators of obligate anaerobic microflora isolated from the vagina of women of group IV were in the range of $\lg 4.4-\lg 6.0 \mathrm{CFU} / \mathrm{ml}$. But in women of group IV seeding rates of Bacteroides spp. and Prevotella spp. significantly exceeded those found in patients of group III (respectively lg6.0 - Ig5.2 CFU/ml).

With a lower frequency than in patients of group III, in patients of group IV, the microbial associations included individual representatives of the intestinal microflora: E.coli 
- 13.3\%, E.coli hem+ - 10.0\%, Klebsiella spp. - 13.3\%, Enterobacter spp. $-6.7 \%$.

The frequency of seeding from the vagina of Firmicutes patients, in particular, gram-positive coccal microflora did not reach significant values: S.aureus - 10.0\%, S.epidermidis (hem+) - 13.3\%. Quantitative indicators of vaginal seeding of facultative-anaerobic microflora were in the range of $\lg 3.5-\lg 4.8 \mathrm{CFU} / \mathrm{ml}$.

The contents of the vagina in women of group IV with a low frequency $(16.7 \%)$ and a small amount included Candida fungi $(\lg 2.8 \mathrm{CFU} / \mathrm{ml})$. Candida albicans was detected with the highest frequency $(6.7 \%)$. The frequency of registration of fungi Candida non-albicans was: C.tropicalis - 3.3\%, C.parapsilosis - 3.3\% (Fig. 4).

In patients of group IV, the indicators of vaginal contamination with lactobacilli did not reach the norm, but were at a higher level $(76.7 \%)$ than in patients of group III in the amount of $\lg 4.2 \mathrm{CFU} / \mathrm{ml}$.

The composition of associations in patients of group IV was represented by 2-4 types of microflora: two-component associations (16.7\%), three-component (50\%), fourcomponent (33.3\%). Five-component bacterial associations were not determined.

\section{Discussion}

Clinical assessment of the condition of the lower genitalia without taking into account the data of microscopy is subjective and does not always allow to detect vaginal dysbiosis in patients [29].

The results of examination of women with vaginosis (groups III and IV) show that obese patients form multicomponent anaerobic-aerobic bacterial communities with a significant content of Gardnerella vaginalis, Atopobium vaginae, as well as Firmicutes with pathogenic properties on the background of low or no normal microflora. As S.I. Klimnyuk and co-authors pointed out in their study (2019): not only Gardnerella vaginalis but also anaerobes Mobiluncus spp., Bacteroides spp., Mycoplasma hominis and other microorganisms are involved in the development of vaginal dysbiosis, and the only cause of bacterial vaginosis there is a violation of the quantitative composition of microorganisms in the vaginal environment on the background of other dysbiotic processes in the body. Complications associated with bacterial vaginosis include chronic inflammation of the internal genitals, the development of adhesions of the pelvic organs, infertility [17].

Some studies suggest that a higher body mass index is associated with increased susceptibility to bacterial vaginosis, but the results are conflicting. Prior to his open cohort study conducted in Mombasa, Kenya, Lookken E.M. with co-authors in 2019 [19] selected women sex workers aged 16 to 45 years. Women who were obese, the authors concluded, had an almost $20 \%$ lower risk of developing bacterial vaginosis compared to women with a normal body mass index. The authors continue to suggest that it is appropriate to study the potential mechanisms of this effect, including the possible effects of diet related to obesity changes in the intestinal microbiome and systemic estrogen levels [19].

At the same time, R.T.Brookheart and co-authors in 2019 [6] showed that bacterial vaginosis is one of the most common vaginal diseases in the United State. Recent studies have shown that in obese women, the abnormal microbiota resembles bacterial vaginosis; however, few studies have examined the prevalence of bacterial vaginosis in overweight and obese population. Moreover, it is not known whether there are racial differences in the ratio of obesity to bacterial vaginosis. In their study, the authors examined the correlation between body mass index and bacterial vaginosis, as determined by the Nugent scale, and identified the influence of race. Overweight and obese women were found to have a higher incidence of bacterial vaginosis than lean women, even after adjusting for race-related variables. Among white women, the prevalence of bacterial vaginosis was higher among overweight women and white women with class I and II/III obesity compared to lean white women, a phenomenon not observed among black women. The authors concluded that overweight and obese women had higher Nugent scores and higher levels of bacterial vaginosis compared to lean women. Interesting was the fact that black women had a higher prevalence of bacterial vaginosis, regardless of their body mass index, compared to white women [6].

Obesity is associated with an increased level of susceptibility to infections, however, the results of clinical studies assessing body mass index and vaginitis are contradictory, G.Ventolini and co-authors pointed out in 2017. They found an association between obesity and recurrent vulvovaginal bacterial infections in women of childbearing potential. The authors proved that obesity can be an independent risk factor for vulvovaginal bacterial infections in women of reproductive age due to altered vaginal immunity [28].

In general, the results of the study of vaginal microbiota in obese women allowed us to identify a significant frequency of two variants of microbiocenosis: candidal vaginitis and vaginal vaginosis, which is confirmed by other studies [21, 27]. The identified variants of vaginal microbiome disorders in patients of our study groups have differences in species and quantitative composition of microbial associations, different indicators of vaginal contamination by Candida fungi, different degrees of imbalance between potentially pathogenic and normal microflora, as indicated by other researchers [24, 28].

The obtained data indicate the feasibility of further development of pathogenetically sound schemes for the treatment of disorders of the vaginal microbiocenosis in obese women.

\section{Conclusions}

1. The composition of vagina microbiota in women of reproductive age with overweight and obesity (groups I and 
II) differs from the composition of the microbiota in women of reproductive age without obesity (groups III and IV) by statistically significant decrease in vaginal contamination by anaerobic microflora, which has a significant metabolic potential: Bacteroides spp. and Prevotella spp. Grampositive anaerobic and facultative-anaerobic microflora of Firmicutes have a significant share in the spectrum of vaginal microflora in overweight and obese patients, in contrast to non-obese women of reproductive age.

2 . In women of reproductive age with vulvovaginal candidiasis who are obese (group I), in contrast to nonobese patients (group II), a higher frequency of fungalbacterial associations, a higher content in the associations of Firmicutes with pathogenic properties and

\section{References}

[1] Aquilera, C., Labbe, T., Busquets, J., Venegas, P., Neira, C., \& Valenzuela, A. (2019). Obesity: risk factor or primary disease? Rev. Med. Chil., 147(4), 470-474. doi: 10.4067/s003498872019000400470

[2] Balasubramanian, R., Paynter, N.P., Giulianini F., Manson, J.E., Zhao, Y., Chen, J.-C.... Rexrode, K.M. (2020). Metabolomic profiles associated with all-cause mortality in the Women's Health Initiative. Int. J. Epidemiol., 49(1), 289-300. doi: 10.1093/ ije/dyz211

[3] Bayramova, G.R., Amirkhanyan, A.S., \& Chernova V.F. (2018). Вульвовагинальный кандидоз: патогенез, диагностика и тактика лечения [Vulvovaginal candidiasis: pathogenesis, diagnosis and treatment tactics]. Доктор.Py - Doctor.Ru, 154(10), 32-36. doi: 10.31550/1727-2378-2018-154-10-32-36

[4] Borovkova, L.V., Ponomareva, I.V., Kosareva, A.A., \& Kolobova, S.O. (2016). Роль Atopobium vaginae в генезе рецидивирующего бактериального вагиноза [The role of Atopobium vaginae in the genesis of recurrent bacterial vaginosis]. Медицинский альманах - Medical almanac, 45(5), 23-28.

[5] Bradshaw, C.S., Tabrizi, S.N., Fairley, C.K., Morton, A.N., Rudland, E., \& Garland, S.M. (2006). The association of Atopobium vaginae and Gardnerella vaginalis with bacterial vaginosis and recurrence after oral metronidazole therapy. J. Infect. Dis., 194(6), 828-836. doi: 10.1086/506621

[6] Brookheart, R.T., Lewis, W.G., Peipert, J.F., Lewis, A.L., \& Allsworth, J.E.(2019). Association between obesity and bacterial vaginosis as assessed by Nugent scorE. Am. J. Obstet. Gynecol., 220(5), 476. doi: 10.1016/j.ajog.2019.01.229.

[7] Brown, R.G., Marchesi, J.R., Lee, Y.S., Smith, A., Lehne, B., Kindinger, L.M. ... MacIntyre D.A. (2018). Vaginal dysbiosis increases risk of preterm fetal membrane rupture, neonatal sepsis and is exacerbated by erythromycin. BMC Med., 16(1), 9. doi: 10.1186/s12916-017-0999-x

[8] Budilovskaya, O.V. (2016). Современные представления о лактобациллах влагалища женщин репродуктивного возраста [Current views on vaginal lactobacilli in women of reproductive age]. Журнал акушерства и женских болезней - Journal of Obstetrics and Women's Diseases, 65(4), 34-43. doi: 10.17816/JOWD65434-43

[9] Budilovskaya, O.V., Shipitsyna, E.V., Gerasimova, E.N., Safronova, M.M., \& Savicheva, A.M. (2017). Видовое разнообразие вагинальных лактобацилл в норме и при дисбиотических состояниях [Species diversity of vaginal lactobacilli in health and dysbiotic conditions]. Журнал акушерства и женских болезней - Journal of Obstetrics and Women's Diseases, 66(2), 24-32. doi: 10.17816/JOWD66224-32
Proteobacterium, a higher quantitative level of vaginal contamination by the fungi Candida albicans and nonalbicans on the background of deficiency or lack of lactoflora observed.

3. The state of microecology of the vagina in women of reproductive age with bacterial vaginosis, overweight and obesity (group III) is characterized by a significant frequency of multicomponent associations, a significant imbalance between the associates of obligate-anaerobic microflora. An increase in vaginosis-associated microflora (Atopobium vaginae, Gardnerella vaginalis, Mobiluncus spp.) and a significant deficiency of Bacteroides spp., Prevotella spp., Lactobacillus spp. was established.

[10] Carrete, L., Ksiezopolska, E., Pegueroles, C., Gomez-Molero, E., Saus, E., Iraola-Guzman, S.... Gabaldon, T. (2018). Patterns of genomic variation in the opportunistic pathogen Candida glabrata suggest the existence of mating and a secondary association with human. S. Curr. Biol., 28, 15-27. doi: 10.1016/ j.cub.2017.11.027.

[11] Chen, Y., Han, X., Guo, P., Huang, H., Wu, Z., \& Liao, K. (2018). Bacteremia Caused by Gardnerella Vaginalis in a Cesarean Section Patient. Clin. Lab., 64(3), 379-382. doi: 10.7754/ Clin.Lab.2017.171035

[12] Dave, C.V., Schneeweiss, S., \& Patorno E.(2019). Comparative risk of genital infections associated with SGLT2 inhibitors: A real-world retrospective cohort study. Diabetes ObeS.Metab., 21(2): 434-438. doi: 10.1111/dom.13531

[13] Gilbert, N.M., O'Brien, V.P., \& Lewis, A.L. (2017). Transient microbiota exposures activate dormant Escherichia coli infection in the bladder and drive severe outcomes of recurrent diseasE.PLoS Pathog., 13(3), doi: 10.1371/ journal.ppat.1006238.

[14] Janulaitiene, M., Paliulyte, V., Grinceviciene, S., Zakareviciene, J., Vladisauskiene, A., Marcinkute, A., \& Pleckaityte, M. (2017). Prevalence and distribution of Gardnerelia vaginalis subgroups in women with and without bacterial vaginosiS.BMC Infect. Dis., 17(1), 394. doi: 10.1186/s12879-017-2501-y

[15] Jespers, V., van de Wijgert, J., Cools, P., Verhelst, R., Verstraelen, H., S.Delany-Moretlwe, S.... Crucitti, T. (2015). The significance of Lactobacillus crispatus and L.vaginalis for vaginal health and the negative effect of recent sex: a cross-sectional descriptive study across groups of African women. BMC Infect. Dis., 15(4), 115. doi: 10.1186/s 12879-015-0825-z

[16] Kira, E.F. (2017). Пробиотики в восстановлении микробиоценоза влагалища [Probiotics in the restoration of vaginal microbiocenosis]. Акушерство и гинекология - Obstetrics and Gynecology, 5, 30-36. https://dx.doi.org/10.18565/ aig.2017.5.32-8

[17] Klymnyuk, S.I., Mykhailyshyn, G.I., \& Malanchuk, L.M. (2019). Мікробіологічні особливості бактеріальних вагінозів у жінок різних вікових категорій та шляхи їх мікробіологічної корекції [Microbiological features of bacterial vaginosis in women of different ages and ways of their microbiological correction]. Здобутки клінічної і експериментальної медицини Achievements of Clinical and Experimental Medicine, 3, 2131. doi: https://doi.org/10.11603/1811-2471.2019.v.i3.10258

[18] Korzh, O.M. (2020). Ожиріння: клініко-патогенетичне обґрунтування профілактики і лікування [Obesity: clinical and pathogenetic rationale for prevention and treatment]. Міжна- 
родний медичний журнал - International Medical Journal, 102(2), 5-11.

[19] Lookken, E.M., Richardson, B.A., Kinuthia J., Mwinyikai, K., Abdalla, A., Jaoko, W. ... McClelland, R.S.(2019). A prospective cohort study of the association between body mass index and incident bacterial vaginosis. Sex Transm. Dis., 46(1), 31-36. doi: 10.1097/OLQ.0000000000000905

[20] Man, A., Ciurea, C.N., Pasaroiu, D., Savin, A.-I., Toma, F., Sular, F. ... MareA. (2017). New perspectives on the nutritional factors influencing growth rate of Candida albicans in diabeticS.An in vitro study. Memrias do Instituto Oswaldo Cruz, 112(9), 587592. https://doi.org/10.1590/0074-02760170098

[21] Medvedev, M.V. (2020). Рецидивуючі вагініти: у центрі уваги вульвовагінальний кандидоз [Recurrent vaginitis: the focus is on vulvovaginal candidiasis]. Медичні аспекти здоров'я жінки - Medical aspects of women's health, 131(2), 131-136.

[22] Mills, B.B. (2017). Vaginitis: beyond the basicS.Obstet. Gynecol. Clin. North Am., 44(2), 159-177. doi: 10.1016/j.ogc.2017.02.010.

[23] O'Neil, A., Russell, J.D., Thompson, K., Martinson, M.L., \& Peters, S.A.E.(2020). The impact of socioeconomic position (SEP) on women's health over the lifetime. Maturitas, 140, 1-7. doi: 10.1016/j.maturitas.2020.06.001

[24] Pestrikova, T.Yu., Yurasova, E.A., \& Kotelnikova, A.V. (2018). Бактериальный вагиноз, сочетанный с цервицитом: эффективность лечения [Bacterial vaginosis associated with cervicitis: the effectiveness of treatment]. Доктор.Pу, Gynecology - Doctor.Ru, Gynecology, 150(6), 30-33. doi: 10.31550/1727-2378-2018-150-6-30-33

[25] Pustotina, O.A. (2018). Бактериальный вагиноз: патогенез, диагностика, лечение и профилактика [Bacterial vaginosis: pathogenesis, diagnosis, treatment and prevention]. Акушерство и гинекология - Obstetrics and Gynecology, 3, 150156. https://dx.doi.org/10.18565/aig.2018.3.150-156
[26] Sherry, L., Kean, R., McKloud, E., O'Donnell, L.E., Metcalfe, R., Jones, B.L., \& Ramage, G. (2017). Biofilms formed by isolates from recurrent vulvovaginal candidiasis patients are heterogeneous and insensitive to FluconazolE.Antimicrob. Agents Chemother., 61(9), 15-17. doi: 10.1128/AAC.01065-17

[27] Tauqeer, Z., Gomez, G., \& Stanford, F.C.(2018). Obesity in Women: Insights for the Clinician. J. Womens Health (Larchmt), 27(4), 444-457. doi: 10.1089/jwh.2016.6196

[28] Ventolini, G., Khandelwal, N., Hutton, K., Lugo, J., Gygax, S.E., \& Schlabritz-Loutsevitch, N. (2017). Obesity and recuirent vulvovaginal bacterial infections in women of reproductive agE. Postgraduate Medical Journal (PMJ), 93(1099), 297. http:// dx.doi.org/10.1136/postgradmedj-2016-134638

[29] Voroshilina, E.S., Zornikov, D.L., \& Plotko, Ye.E.(2017). Hopмальное состояние микробиоценоза влагалища: оценка с субъективной, экспертной и лабораторной точек зрения [The normal state of the vaginal microbiocenosis: an assessment from the subjective, expert and laboratory points of view]. Вестник Российского государственного медицинского университета, Научный медицинский журнал имени Н.И.Пирогова - Bulletin of the Russian State Medical University, Scientific Medical Journal named after N.I.Pirogov, 2, 42-46. doi: 10.24075/brsmu.2017-02-06

[30] Zilberberg, N.V., Grekova, Yu.N., Levchik, N.K., Evstigneeva, N.P., Voronova, O.A., \& Gerasimova N.A. (2018). Принципы терапии бактериального вагиноза, ассоциированного с Gardnerella vaginalis и Atopobium vaginae, у женщин репродуктивного возраста [Principles of therapy for bacterial vaginosis associated with Gardnerella vaginalis and Atopobium vaginae in women of reproductive age]. Вопросы гинекологии, акушерства и перинатологии - Questions of Gynecology, Obstetrics and Perinatology, 17(6), 19-25. doi: 10.20953/1726-1678-2018-6-19-25

\section{ОСОБЛИВОСТІ МІКРОБІОЦЕНОЗУ ПІХВИ У ЖІНОК РЕПРОДУКТИВНОГО ВІКУ 3 НАДЛИШКОВОЮ МАСОЮ ТІЛА ТА ОЖИРІнНЯ \\ Гаспарян К.А., Кондратюк В.К., Пономарьова І.Г., Кондратюк К.О., Дзісь Н.П., Лисяна Т.О.}

Надлишкова вага та ожиріння відіграють негативну роль в гінекологічній та акушерській практиці. У жінок збільшується частота інфекційної патології на фоні метаболічних розладів. Найбільш розповсюджена форма інфрекційного вагініта - це бактеріальний урогенітальний кандидоз, в етіологічній структурі якого визначна роль належить грибам Candida albicans, а також Candida non-albicans: C.glabrata, C.tropicalis, C.parapsilosis, C.krusei. Нерідко формуються асоціації грибів р.Candida з різними представниками умовно патогенної мікрофрлори, такими як грампозитивні та грамнегативні аеробні, фракультативно-анаеробні та облігатно-анаеробні мікроорганізми. Внаслідок цього розмножуються багаточисленні бактеріальні збудники та суттєво зменшується кількість лактобактерій, які зазвичай є у складі бактеріальної фрлори вагіни. При бактеріальному вагінозі концентрація анаеробних патогенів Peptostreptococcus sp, Gardnerella vaginalis, Peptostreptococcus Mobiluncus sp, Mycoplasma hominis може збільшуватись у 100 разів. Доведено активацію Atopobium vaginae ma Gardnerella vaginalis, що відіграють "ключову" роль у патогенезі БВ. Метою роботи стало вивчення змін мікробіому піхви у жінок з кандидозом та бактеріальним вагінозом з метою удосконалення існуючих схем терапії. Обстежили 120 жінок репродуктивного віку з надлишковою вагою та ожирінням. Визначали ступінь мікробного обсіменіння та виявляли максимально можливий спектр аеробної та фракультативно-анаеробної мікрофрлори. У жінок з вульвовадінальним кандидозом, надлишковою вагою і ожирінням встановлена висока концентрація (Ig5,8 КУО/мл) грибів p.Candida, а у 95\% хворих фрормувались двух-, трьох- та чотирьохкомпонентні асоціації грибів р.Cаndida з різними представниками умовно-патогенної мікрофрлори. Дефріцит лактобацил встановлений у 58,3\% хворих, а їх повна відсутність - у 10,0\%. Бактеріологічне дослідження вмісту піхви жінок з вагінозом та ожирінням виявило значні дисбіотичні порушення складу піхвової мікрофрлори, трьох-, чотирьохта навіть п'ятикомпонентні асоціації анаеробної та факультативно-анаеробної мікрофолори з домінуванням анаеробів. Встановлений низький рівень висіву лактобацил (Ig2,2 КУО/мл). Таким чином, значну питому вагу в спектрі мікрофлори піхви у пацієнток з надлишковою вагою та ожирінням, на відміну від жінок репродуктивного віку без ожиріння, має грампозитивна анаеробна та фракультативно-анаеробна мікрофрлора фрілуму Firmicutes. У жінок репродуктивного віку 3 кандидозним вульвовагінітом та ожирінням, на відміну від пацієнток без ожиріння, встановлена більш висока частота грибково-бактеріальних асоціацій, більш високий кількісний рівень контамінації піхви грибами Candida albicans ma nоnalbicans на фоні дефiциту або загальної відсутності лактофрлори.

Ключові слова: надлишкова маса тіла, ожиріння, мікробіоценоз, бактеріальний вагіноз, урогенітальний кандидоз. 